\title{
'Spirulina' as an Additive for Better Nutrition
}

\author{
Supriya Shinde, Shivaji A. Lavale* and Kiran Nagare \\ College of Agricultural Biotechnology, Ahmednagar, MS, India \\ *Corresponding author
}

\begin{abstract}
A B S T R A C T
Keywords

Spirulina snacks,

Shankarpali,

Nutritional value

Article Info

Accepted:

04 April 2018

Available Online:

10 May 2018

The snacks were prepared by using spirulina as an ingredient with different concentrations. Proximate composition analysis was done to estimate moisture, protein, fat, carbohydrate, ash and energy content of the snacks. Nutritional value of the snacks was found to be increased with increase in the concentration of the spirulina. Organoleptic evaluation led to selection of $5 \%$ concentration of spirulina to be better when compared with $10 \%$ and $15 \%$. Addition of spirulina not only increased the nutritional value of the product but also influenced the textural properties and quality characteristics.

\section{Introduction}

Spirulina (Spirulina platensis) is blue - green algae that thrive in warm, alkaline fresh-water bodies. It is cultivated all around the world and is used as a human dietary supplement as well as whole food which are available in tablet, flake and powder form. Spirulina provides a wide range of health benefits almost immediately upon ingestion. It boosts the immune system, lowering cholesterol, heart health, diabetes treatment, wound healing, improving digestive health and as an antidote to depression and anxiety. Spirulina is also a natural detoxifier, oxygenating the blood, and helping cleanse the body of toxins and other impurities that may be causing illnesses or other health complications. Moreover, most research has focused on the

health effects of spirulina as a dietary supplement for humans and therapeutic applications: an anti-cancer effect (Mao et al., 2005), a hypolipidemic effect (Narmadha et al., 2012), and a protective effect against diabetes and obesity (Anitha and Chandralekh, 2010). These advantages make spirulina a good raw material for the healthy food.

Inclusion of spirulina as ingredient to the different food materials can improve the nutritional value of that food. Snacks such as cookies have low water content, which protects them from microbial spoilage and provides longer shelf life. Cookies are very popular, easy-to-eat products consumed all over the world. Unfortunately, such products in the market very often contain fat rich in saturated fatty acids and trans fatty acids.
\end{abstract}


However, products with wholegrain flour and dried fruits are becoming more popular due to the consumers' increasing awareness of healthy life style.

Scientific papers report possibilities of using bioactive compounds such as: dietary fibers (Demirkesen, 2016), plant extracts (Mildnerszkudlarz et al., 2009), fruit pomaces in bakery products (Bajerska et al., 2016) and legume flours (Cheng and Bhat, 2016). Addition of such ingredients may very often have adverse impact on textural properties and sensory characteristics.

Addition of spirulina as an ingredient in food not only increase nutritional value of such products but also influence the textural properties and quality characteristics. Addition of even small amounts of Spirulina has a strong impact on sensory characteristics like color, smell, taste and texture of a product (Kumoro et al., 2016). Addition of spirulina to snacks recipes may influence both physical parameters and overall acceptability. The aim of this work was to analyse physical and sensory properties of snacks viz. Shankarpali supplemented with different amounts of spirulina.

\section{Materials and Methods}

\section{Preparation of spirulina snacks}

All the preparations were made at Food technology laboratory, College of Agricultural biotechnology, Ahmednagar, MS, India. Spirulina snacks (Shankarpali) was prepared using spirulina powder (obtained from Spirulina Production Research and Training Centre, Ahmednagar, MS, India) with three different concentrations viz. 5\%, 10\% and $15 \%$ along with control with no spirulina (Table 1). Refined and good quality wheat flour was added with spirulina powder and 5\% corn floor. Presterilized whey water was used to prepare dough which was cut into rectangular shape pieces using knief. These were fried in vegetable oil in an open pan and stored.

\section{Estimation of proximate composition}

Proximate composition analysis viz. Moisture content, Total ash content, Protein content, Crude protein content, Crude carbohydrate, Crude fat and Energy was done for the prepared product according to A.O.A.C., (2000).

\section{Moisture}

Moisture content was worked out by subjecting $5 \mathrm{gm}$ sample to oven drying at $110^{\circ} \mathrm{C}$ for $4-5 \mathrm{hrs}$ until the constant weights were obtained. The resultant loss in weight was calculated as percent moisture content using formula, Moisture $(\%)=\left[\mathrm{W}_{1^{-}}\right.$ $\left.\mathrm{W}_{2} / \mathrm{W}_{1}\right] \times 100$, Where, $\mathrm{W}_{1}=$ Initial weight of sample and $\mathrm{W}_{2}=$ Final weight of sample.

\section{Total ash}

For estimation of total ash content $5 \mathrm{~g}$ sample was weighed into crucible and ignited at low flame till all the material was completely charred. Then it was kept in muffle furnace for $6 \mathrm{hrs}$ at $600^{\circ} \mathrm{C}$ and further cooled in desiccators and weighed. This was repeated till two consecutive weights were constant and per cent ash was calculated using formula, Total ash $(\%)=\left[\mathrm{W}_{1}-\mathrm{W}_{2} / 5\right] \times 100$, Where, $\mathrm{W}_{1}=$ weight of crucible with sample and $\mathrm{W}_{2}=$ weight of crucible with ash.

\section{Crude protein}

Protein content was determined by estimating the per cent nitrogen according to A.O.A.C., (2000) with Kjeldahl's method and then converted into protein content as, \% Crude protein content $=$ nitrogen content $\times$ 6.25. 


\section{Carbohydrate}

For estimation of crude carbohydrate (DNS method) about $0.1 \mathrm{~g}$ sample was weighed into $25 \mathrm{ml}$ volumetric flask. $1.3 \mathrm{ml}$ of $62 \%$ perchloric acid was added with continuous shaking for 20 minutes to homogenize the mixture completely. The volume was made up to $25 \mathrm{ml}$ using distilled water. The solution was filtered and $1 \mathrm{ml}$ of the filtrate was transferred to $10 \mathrm{ml}$ volumetric flask and diluted to volume with distilled water. $11 \mathrm{ml}$ of this working solution was taken into a clean test tube and $5 \mathrm{ml}$ of anthrone reagent was added. Absorbance of the standard glucose was recorded at $630 \mathrm{~nm}$ and the value of the carbohydrates was calculated using the formula, $\%$ carbohydrates $=25 \times$ Absorbance of sample/Absorbance of standard $\times 1 \mathrm{~g}$.

\section{Crude fat}

Crude fat content was analysed with Soxhlet's method. One gram of the dried sample was transferred to a paper thimble, plugged at the opening with glass wool and placed into a thimble holder. $200 \mathrm{ml}$ of petroleum ether was taken into a previously dried and weighed round-bottom flask and this was assembled together with the thimble holder and its contents. The Quickfit condenser was connected to the Soxhlet Extractor and refluxed for 16 hours on low heat on a heating mantle. The flask was then removed and the solvent evaporated on a steam bath. The flask containing the fat was heated at $105^{\circ} \mathrm{C}$ in an oven for 30 minutes, cooled in a desiccator and the weight of the fat collected determined and expressed as percentage crude fat using the formula, Crude Fat $(\%)=$ Weight of Fat/ Weight of original sample $\times 100$

Energy is calculated by multiplying protein and carbohydrate content by 4 and fat content by 9 . Total energy $=4$ (Protein content+ carbohydrate content) +9 fat content.

\section{Organoleptic evaluation}

Prepared spirulina snacks with three different concentrations of spirulina powder was evaluated for acceptance for its appearance, colour, texture, odour and taste. This evaluation was done by a panel of six members using 5 point hedonic scale.

\section{Results and Discussion}

\section{Proximate composition of spirulina snacks}

Snacks prepared using spirulina with different concentrations viz. 5\%, 10\% and 15\% (Fig. 1) were subjected to proximate composition analysis (Table 2). No significance difference was observed in control ant treatments for Moisture, carbohydrate and ash content. However, protein and fat content were observed to increase with increase in the spirulina concentration, with significant difference, suggesting role of spirulina.

\section{Fig.1 Snacks prepared with different concentrations of spirulina}

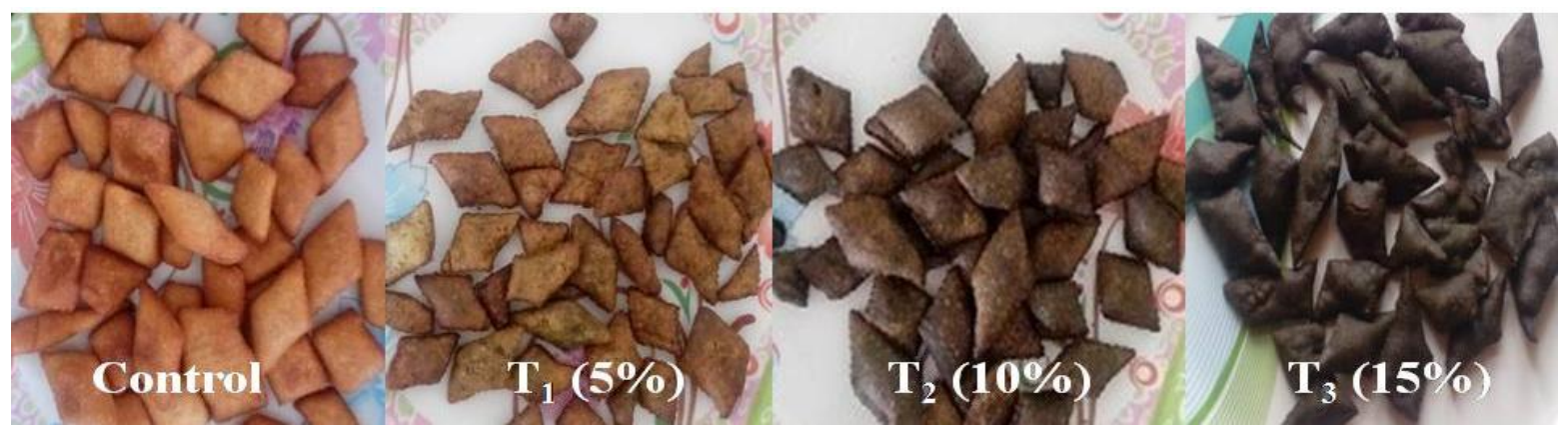


Table.1 Ingredients used for spirulina snacks

\begin{tabular}{|l|c|c|c|}
\hline Group & Refined wheat flour(g) & Spirulina (g) & Corn flour (g) \\
\hline Control & 100 & - & - \\
\hline $\mathrm{T}_{\mathbf{1}}(\mathbf{5} \%)$ & 90 & 5 & 5 \\
\hline $\mathrm{T}_{2}(\mathbf{1 0} \%)$ & 85 & 10 & 5 \\
\hline $\mathrm{T}_{\mathbf{3}}(\mathbf{1 5 \%})$ & 80 & 15 & 5 \\
\hline
\end{tabular}

Table.2 Proximate composition of value added product

\begin{tabular}{|c|c|c|c|c|}
\hline Parameter* & Control & $\mathrm{T}_{\mathbf{1}}(\mathbf{5 \%})$ & $\mathrm{T}_{\mathbf{2}}(\mathbf{1 0 \%})$ & $\mathrm{T}_{\mathbf{3}}(\mathbf{1 5 \%})$ \\
\hline Moisture (\%) & $5.15 \pm 0.03$ & $4.86 \pm 0.10$ & $5.12 \pm 0.14$ & $5.31 \pm 0.64$ \\
\hline Protein (\%) & $17.42 \pm 0.18$ & $21.18 \pm 0.61$ & $23.90 \pm 0.73$ & $24.27 \pm 0.95$ \\
\hline Carbohydrate (\%) & $20.40 \pm 0.41$ & $19.11 \pm 1.00$ & $17.19 \pm 1.03$ & $18.29 \pm 2.32$ \\
\hline Fat (\%) & $2.23 \pm 0.06$ & $2.95 \pm 0.13$ & $3.27 \pm 0.22$ & $3.70 \pm 0.07$ \\
\hline Ash (\%) & $54.5 \pm 0.46$ & $52.10 \pm 0.38$ & $50.67 \pm 0.69$ & $48.17 \pm 0.91$ \\
\hline
\end{tabular}

*Mean of 3 replications

Table.3 Organoleptic acceptability of value added product

\begin{tabular}{|c|c|c|c|c|c|c|}
\hline $\begin{array}{c}\text { Proportion of } \\
\text { Spirulina } \\
\text { powder }\end{array}$ & Appearance & Colour & Texture & Odour & Taste & $\begin{array}{c}\text { Over all } \\
\text { acceptability }\end{array}$ \\
\hline $\mathrm{T}_{1}(\mathbf{5} \%)$ & 5 & 5 & 4 & 4 & 4 & 4.4 \\
\hline $\mathrm{T}_{2}(\mathbf{1 0} \%)$ & 4 & 4 & 4 & 4 & 3 & 3.8 \\
\hline $\mathrm{T}_{\mathbf{3}}(\mathbf{1 5 \%})$ & 4 & 4 & 4 & 4 & 3 & 3.8 \\
\hline
\end{tabular}

Vijayarani et al., (2012) also found higher protein content in developed product (pasta) using spirulina. Sharma and Dunkwal (2012) also observed increased crude protein content in developed product with the inclusion of spirulina. Thus, spirulina is confirmed to be a promising additive to be used for snacks preparation. Consumption of such snacks on daily basis can reduce the problem of malnutrition from all the age groups.

\section{Organoleptic evaluation}

Snacks with $5 \%$ spirulina had more acceptance than other concentrations. In case of T2 (10\%) and T3 (15\%), snacks was not preferred mainly because of its appearance and colour which was darker than control and T1 (Fig. 1 and Table 3). Moreover, those were not accepted for its texture, odour and taste as well because it deviated a lot from the control.

\section{References}

Anitha, L. and Chandralekha, K., 2010, Effect of supplementation of spirulina on blood glucose, glycosylated hemoglobin and lipid profile of male non-insulin dependent diabetics. Asian j. exp. biol. sci., 1 (1):36-46.

AOAC, 2000, Official methods of analysis, 17th Ed. Association of Official Analytical Chemists, Inc. Washington, USA. 
Bajerska, J., Mildner-Szkuldarz, S., Gornas, P. and Seglina, D., 2016, The effects of muffins enriched with sour cherry pomace on acceptability, glycemic response, satiety and energy intake: a randomized crossover trial. J. Sci. Food Agr. 96(7): 2486-2493.

Cheng, Y. F. and Bhat, R., 2016, Functional, physicochemical and sensory properties of novel cookies produced by utilized jering (Pithecellobium jiringa Jack.) legume flour. Food Biosci. 14:54-61.

Demirkesen, I., 2016, Formulation of chestnut cookies and their rheological and quality characteristics. J. Food Qual. 39 (3):264-273.

Kumoro, A. C., Johnny, D. and Alfilovita, D., 2016, Incorporation of microalgae and seaweed in instant fried wheat noodles manufacturing: nutritional and culinary properties study. Int. Food Res. 23(2):715-722.

Mao, T., Van de Water, J. and Gershwin, M., 2005, Effects of a spirulina-based dietary supplement on cytokine production from allergic rhinitis patients. Journal of Medicinal Food, 8: 27-30.

Mildner-Szkudlarz, S., Zawirska-Wojtasiak, R., Obuchowski, W. and Goslinski, M., 2009, Evaluation of antioxidant activity of green tea extract and its effect on biscuits lipid fraction oxidative stability. J Food Sci. 74: 362-370.

Narmadha, T., Sivakami, V., Ravikumar, M. and Mukeshkumar, D., 2012, Effect of spirulina on lipid profile of hyperlipidemics. World Journal of Science and Technology, 2: 19-22.

Sharma, V. and Dunkwal, V., 2012, Development of spirulina based "biscuits": a potential method of value addition, Ethno Med, 6(1): 31-34.

Vijayarani, D., Ponnalaghu, S. and Rajathivya, J., 2012, Development of value added extruded product using spirulina. International Journal of Health Sciences and Research, 2(4): 4247.

\section{How to cite this article:}

Supriya Shinde, Shivaji A. Lavale and Kiran Nagare. 2018. 'Spirulina' as an Additive for Better Nutrition. Int.J.Curr.Microbiol.App.Sci. 7(05): 143-147. doi: https://doi.org/10.20546/ijcmas.2018.705.018 